\title{
TRANSPARENT LEAVES EDUCATION TO BE PAINTING AND CRAFTS
}

\author{
Putri Suryandari and Tutik Asmawi \\ Universitas Budi Luhur, Indonesia \\ putri.suryandari@budiluhur.ac.id
}

\begin{abstract}
Education of processing transparent leaves into paintings, is a research application for processing leaves waste into transparent leaves as interior wall hangings. Application in the form of training for lecturers and students of 8 architectural study programs in Jakarta in collaboration with Budi Luhur Architecture study programs in Green Architecture activities.

The training method in the form of presentations and painting activities directly in the field with the media of drawing paper, glue, watercolors and scissors.

The end result produces various images in 2 Dimensions and 3 Dimensions. Then proceed with the exhibition of paintings and crafts from transparent leaves by 8 PTS.
\end{abstract}

Keywords: Transparent Leaves, Interior Products, Transparent Leaves Painting, Wall Decoration

\section{INTRODUCTION}

Architecture Study Program Budi Luhur in collaboration with Japan's Kagoshima University, in 2014 conducted a research on the processing of leaf waste (Happa) which was decomposed into transparent leaves. The processing system is very low budget, can produce transparent aesthetics that are very aesthetic. The result is that transparent leaves can be developed into handicraft products.

The results of this study were then developed into interior products, especially wall hangings, the result is transparent leaf paintings get the highest value to be developed. Referring to the results of this study, the development is, to empower the community in the cultivation of transparent leaves into a creative economy.

So that this goal can be absorbed properly, then 8 PTS architecture study programs that are incorporated in the 8 PTS Architecture Study Program in Jakarta in the field of Green Architecture, requested to create an educational program for lecturers and students of 8 PTS (UKI, UMJ, UBK, BL, UPI YAI, Pancasila, and Borobusur) to process transparent leaves into paintings and crafts. The results of this education will be further developed by each study program to empower the community around the campus.

\section{Problems}

Based on the background above, the authors get the following questions:

"What kind of transparent leaf paintings and handicraft products that are efficient, effective and aesthetic to be developed in the community?"

\section{Purpose and Output}

This educational activity is expected to produce

a. Efficient, effective and aesthetic painting and craft products

b. Painting and craft product exhibition

\section{Benefits}

a. For the government, as a contribution of thought in its public policy related to the development of leaf waste into the creative industry, for the ultimate goal of public welfare.

b. For entrepreneurs, as a contribution in the development and economization of creative industry products in the Interior field which in turn provides employment for the community.

c. For the community, as a contribution of ideas and stimuli in the creation, distribution, and consumption of transparent leaf creative industry products. 


\section{THEORY STUDY}

\section{Processing Waste Leaves into Transapran Leaves (Putri, 2014)}

The study was conducted by Budi Luhur University, Putri Suryandari, ST, M.Ars and Hj Tutik Asmawi (Cooperation with Kagoshima University) (2014), with the title; Green Leaf Decomposition Process into Transparent Leaves with mud media, Leaf Waste has a very large amount in Indonesia and throughout the world. Leaf litter is usually used as compost or left alone because it breaks down easily. Leaves that have been transformed into Transparent Leaves can generally be used as high value craft items.

In collaboration with Kagoshima University, we are looking for the fastest process in decomposing green leaves into transparent leaves, using mud and water. The method used is an experiment, through stages, 1) Selection of the type of mud, 2) Calculation of leaf decomposition time, 3) Measurement of the strength of the post-leaf leaf bone.

Utilization of sludge from catfish farming has the ability to decompose leaves quickly, from the beginning two months of harvest, now it can be harvested in the amount of hundreds of leaves. after three days. The strength of the experimental results of green decomposition of leaves with mud into transparent leaves is 5 years.

\section{Processing Transparent Leaves into a suction wall for the interior (Putri 2018)}

Leaves that are decomposed into transparent leaf bones have a very aesthetic appearance. The diversity of leaf shapes and the increasingly abundant decomposition results require innovative applications and high selling value. This research aims to produce interior products that meet the needs of the community and are economical.

The research method is an experimental method, which is to make several forms of paintings as interior wall hangings, to be offered to the public. The offer is carried out in the form of the Transparent Leaf exhibition. The choice of design is adjusted to the user's taste. Based on the results of product sales trials, at three times exhibition of transapan leaf painting products using canvas media, $90 \%$ were sold. Even at the first exhibition, there were several orders that entered because all the products were sold out. The number of buyers with the order model gets the most, from the type of painting purchase.

Painting with the theme of trees has the highest number of productions and buyers, which is $60 \%$ of all products. Birds and trees $18 \%$, Peacocks $8 \%$, flowers and wreaths $14 \%$.

\section{METHODE}

\section{Raw material}

The leaves used to be transparent leaves generally consist of soursop leaves, teak leaves and sandpaper leaves. The leaves are decomposed by soaking in the mud, for about three days.

Furthermore, transparent leaves through the coloring process. The process of coloring transparent leaves is using textile dyes. Transparent leaves are boiled in a pan together with textile coloring, for about 15 minutes. After that, the leaves are drained and dried / dried.

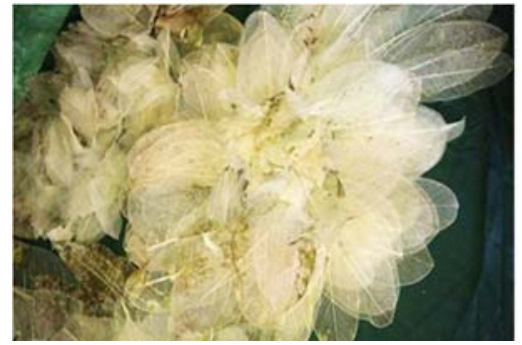

Figure 1. Transparent leaf before color (Sandpaper leaves and Soursop leaves)

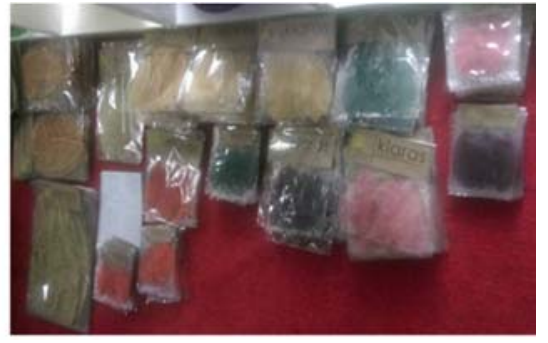

Figure 1. Transparent leaf before color (Sandpaper leaves and Soursop leaves)

\section{Wall Decoration Design Process}

Based on product data that has been made and marketed to the community. So in this study using products that are not yet on the market. The initial process is to conduct a trial at the level of product importance (basic products, expected products and potential products). The product tested is for wall decoration.

The wall decoration that was tested was a painting of transparent leaves. The media used are glass and canvas. Process Design

There are 4 alternative painting designs, including: 
a. Tree design

There are two types, shade trees and trees with deciduous trees.

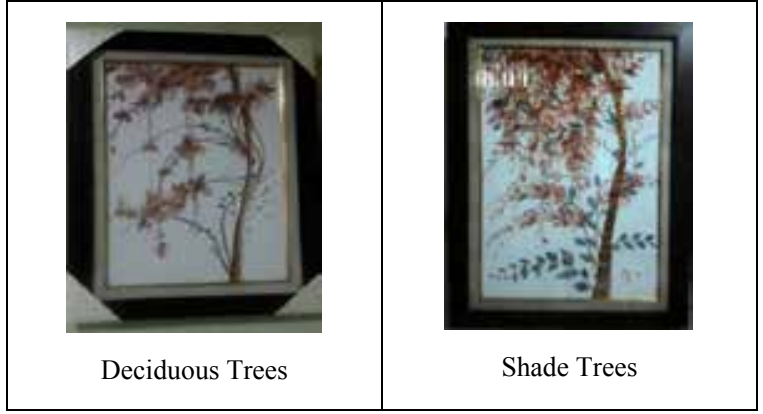

\section{b. Peacock Design}

There are two types, peacock with feathers from a single leaf and peacock with feathers from a pile of leaves.

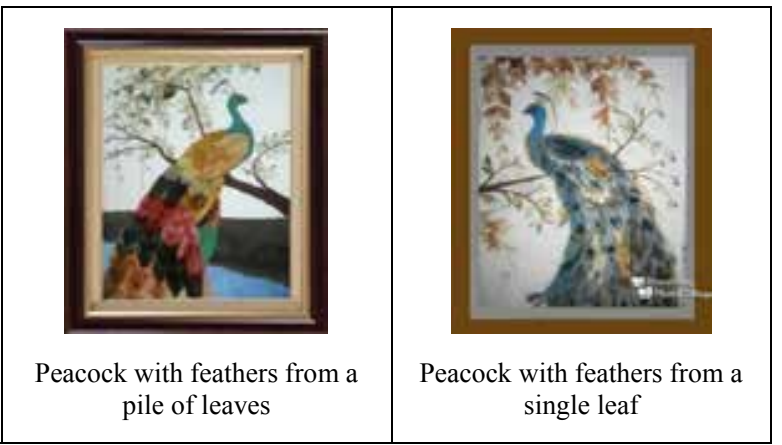

c. Birds on a tree

There are two types of bird and tree painting models. A pair of birds and a flock of birds

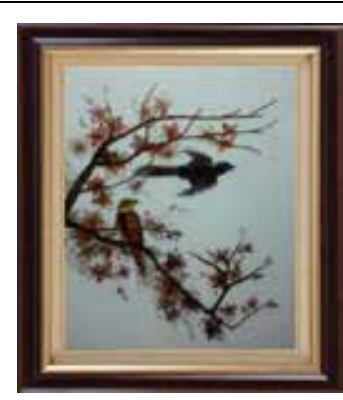

A pair of birds

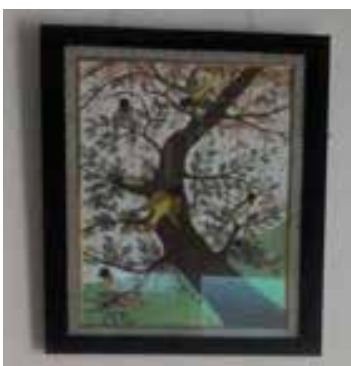

A flock of birds

d. Flower Design / Bouquets

There are two types of painting models of Flowers / floral arrangements.

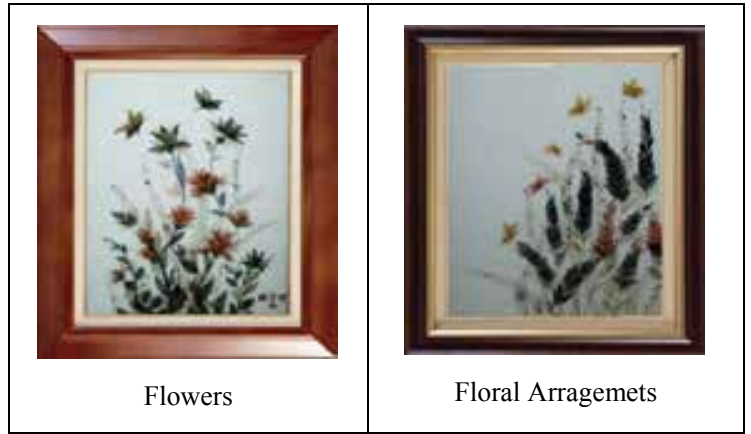




\section{Making process}

a. Play Media

Canvas and Glass

b. Supporting material

Glue, scissors, pencil, eraser, brush, and watercolor / acrylic paint

c. Measure $40 \mathrm{~cm}$ x $60 \mathrm{~cm}$

The process of making with Canvas Main Media, requires designs that are painted first on canvas. Initial sketch using pencil, after that emphasized with watercolor / acrylic / oil paint.

The painted object is usually only a support of the main object, such as trees and branches. The main objects such as leaves, and / or feathers of birds, are scissors first then directly attached to the canvas.

The process of making with Glass Main Media, requires the initial design that is painted on paper, then paste while behind the glass. The main object of transparent leaves is directly attached to the surface of the glass, following the design underneath.

The leaves are placed on the main media using glue. Before the paste, the leaves are cut and processed according to the desired design.

Watercolor / acrylic is used to finish pictures that have been pasted on the main media.

The best glue to use is Fox white glue. Can stick to strong and no trace after cleaning.

For finishing in strengthening the leaves that have been installed in the painting, it is necessary to glue in front of the leaves. Can be strengthened through two times gluing.

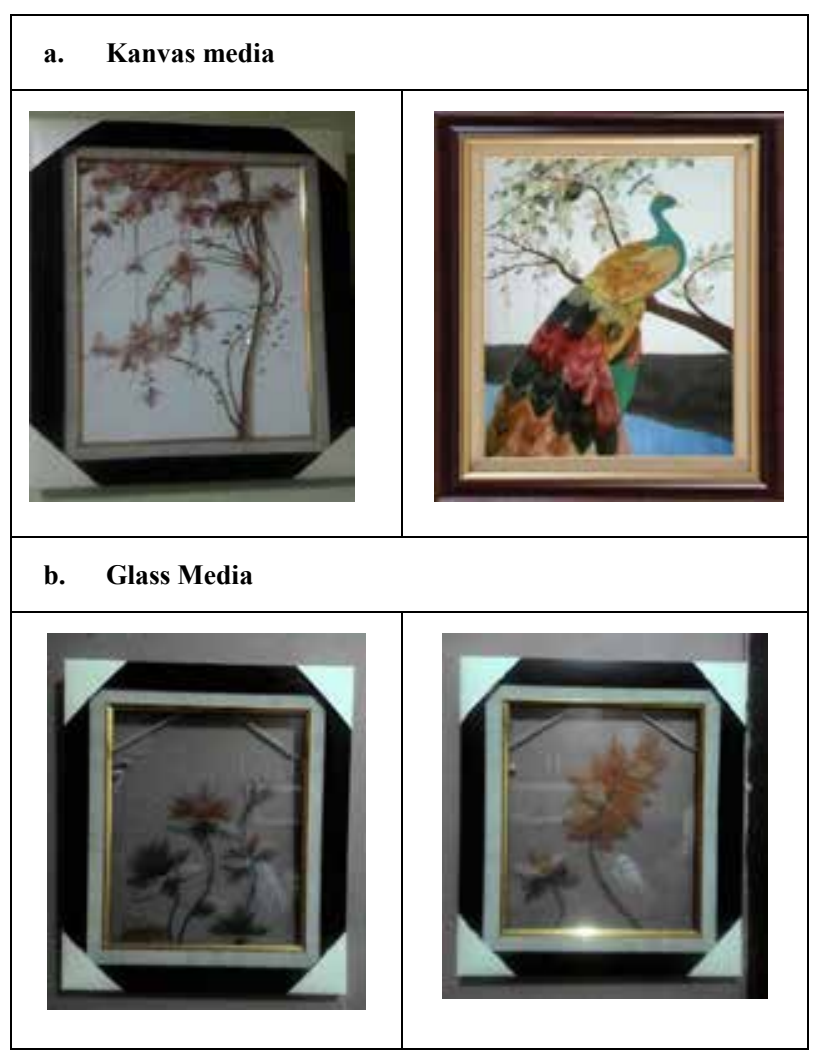




\section{RESULT AND DISCUSSION}

The training was conducted at the Laboratory of Image Studio Architecture Study Program, FT Budi Luhur. Each PTS that is present is represented by one lecturer and one student.

Selection of design tailored to taste. Some choose to design birds, plants, flowers or humans.
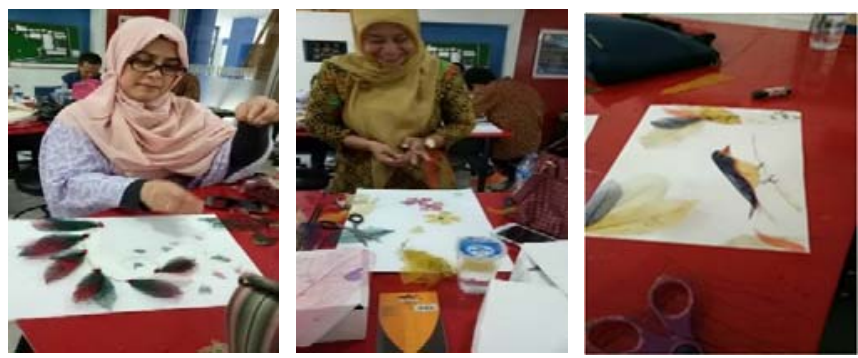

Painting Training

Effective training is first by giving examples of designs to be applied together. After that the choice of colors and accessories is made on the creativity of the participants. Furthermore, participants began to be able to create their own, the form of paintings and creations of transparent leaf crafts, according to their ideas and ideas.
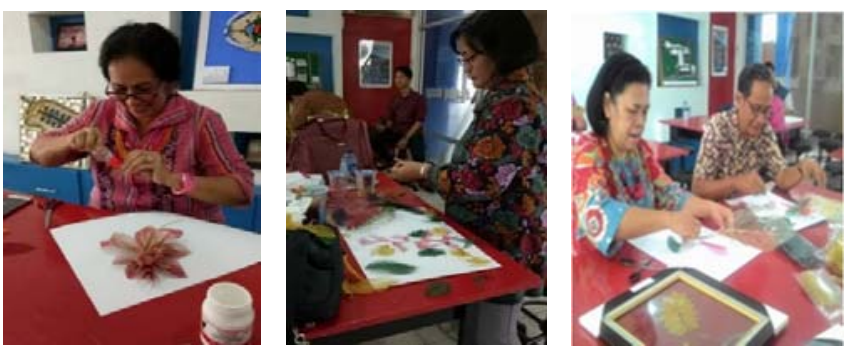

Painting Training

Painting with the theme of trees has the highest number of enthusiasts, which is $60 \%$ of all products. Birds and trees $18 \%$, Peacocks $8 \%$, flowers and wreaths $14 \%$.

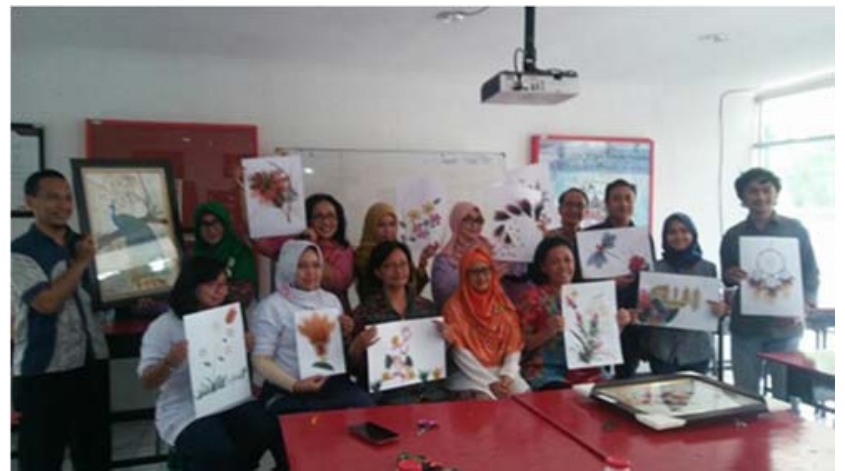

Results of training in painting with transparent leaves

The picture below is the result of paintings and crafts on display at the UKI Jakarta campus.
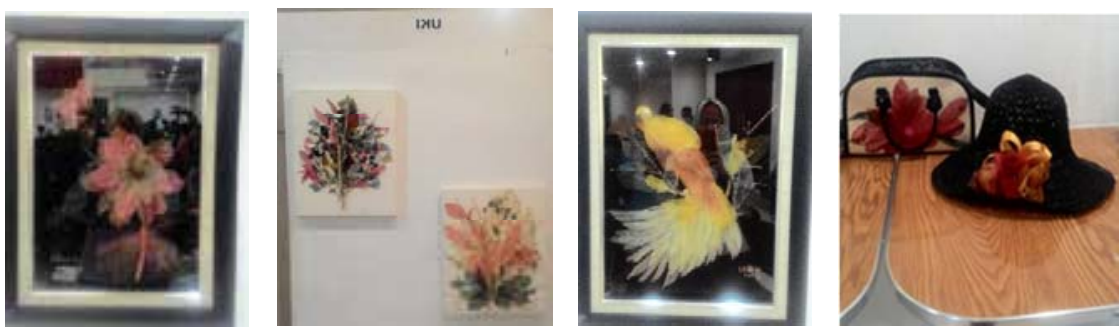

Painting and Craft 


\section{CONCLUSION}

Transparent leaf painting in addition to being different, also suits the tastes of almost all walks of life. Not limited only to art fans. It was proven when the buyer camera consisted of various groups.

In general, the processing of transparent leaves into wall hangings has huge prospects for the creative industry.

In the practice of innovating the making of transparent leaf paintings and crafts, the participants were very fast in generating creative and interesting ideas. So that the Transadian Leaf exhibition held at the Indonesian Christian University Auditorium (UKI) very diverse products were produced.

\section{REFERENCES}

1. Putri Suryandari, ST,M.Ars, Leaf Waste Procesing Into Transparent Leaves For Interior Wall Decoratior, Proceeding book, The $8^{\text {th }}$ Anual Basic Science International Conference, March 2018

2. Putri Suryandari, ST,M.Ars dan Hj Tutik Asmawi, Proses Dekomposisi Hijau daun menjadi Daun Transparan dengan media Lumpur, Laporan penelitian Paten BL 2017.

3. Anggraeni Dyah, Sri Kurniasih, Putri Suryandari, Kampung Petani Sampah di Kamal Jakarta Barat, Laporan PPM DRPM Dikti 2017.

4. Anggraeni Dyah, Sri Kurniasih, Putri Suryandari, IbM Menuju Kampung Recycle di Petukangan Utara, Laporan PPM DP2M Dikti 2014. 